\title{
Scientific Production of Researchers from the Brazilian Council for Scientific and Technological Development (CNPq) in the Neuroscience area
}

\section{Produção Científica dos Pesquisadores do Conselho Nacional de Desenvolvimento Científico e Tecnológico (CNPq) na Área da Neurociência}

\author{
Gabriela Pereira Dias ${ }^{I}$ iD \\ Daniella Reis Barbosa Martelli ${ }^{I}$ i \\ Simone de Melo Costa ${ }^{I}(\mathbb{D}$ \\ Rodrigo Soares de Andrade ${ }^{I I}$ (D) \\ Eduardo Araújo Oliveira ${ }^{I I I}$ (DD \\ Hercílio Martelli Júnior ${ }^{I}$ (iD
}

\section{KEYWORDS}

- Bibliometric indicators.

- Scientific Production.

- Neuroscience.
I Universidade Estadual de Montes Claros, Montes Claros, Minas Gerais, Brazil.

${ }^{\mathrm{I}}$ Universidade Estadual de Campinas, Campinas, São Paulo, Brazil.

${ }^{\mathrm{III}}$ Universidade Federal de Minas Gerais, Belo Horizonte, Minas Gerais, Brazil. 


\section{PALAVRAS-CHAVE}

- Indicadores Bibliométricos.

- Produção Científica.

- Neurociência.

\section{RESUMO}

Introdução: Este estudo avaliou o perfil e a produção científica dos bolsistas do Conselho Nacional de Desenvolvimento Científico e Tecnológico (CNPq) na área de neurociência. Método: Construiu-se um banco de dados com os 542 pesquisadores em medicina cadastrados como bolsistas do CNPq. Desse montante de pesquisadores, 94 (17,34\%) tinham a área de neurociência como principal campo de pesquisa. Resultados: Todos os 94 pesquisadores da neurociência estavam distribuídos em oito estados brasileiros: São Paulo ( $n=$ 49; 52,12\%), Rio Grande do Sul ( $n=22 ; 23,40 \%)$, Rio de Janeiro ( $n=9 ; 9,57 \%)$, Minas Gerais $(n=5 ; 5,31 \%)$, Ceará $(n=4 ; 4,25 \%)$, Santa Catarina $(n=3 ; 3,19 \%)$, Espírito Santo $(n=1 ; 1,06)$ e Paraná $(n=1,1,06 \%)$. Quanto à instituição de origem, os pesquisadores da neurociência distribuíram-se por 20 instituições diferentes no país. No entanto, três instituições foram responsáveis por aproximadamente 58,50\% dos pesquisadores: USP $(n=30)$, UFRGS $(n=15)$ e Unifesp $(n=10)$. A mediana do tempo desde a obtenção do título de doutor foi de 18,27 anos (IQ, 5-39). Ao longo da carreira acadêmica, os 94 pesquisadores publicaram 16.488 artigos em periódicos científicos, com uma média de 175,40 artigos por pesquisador (variando de 43 a 715 artigos). Dos 16.488 artigos, 12.801 (77,63\%) foram indexados na Web of Science (média de 136,18 artigos/pesquisador) e 10.166 (61,65\%) na base Scopus (média de 108,14 artigos/pesquisador). Durante a carreira, os bolsistas orientaram 1.279 estudantes de iniciação científica (mediana de 13,60; intervalo: 0-68), 1.329 estudantes de mestrado (mediana de 14,13; intervalo: 1-49) e 970 de doutorado (mediana de 10,54; intervalo: 0-42). O índice $H$ mediano no ISI dos bolsistas foi de 23,75. Conclusões: Observa-se que os pesquisadores da neurociência constituem um grupo com expressiva produção científica (índice H mediano no ISI de 23,75). A maioria dessas publicações científicas se encontrava nas bases Web of Science (77,63\%) e Scopus (61,65\%). Também se destacou a formação qualificada de recursos humanos, incluindo iniciação científica, mestrado e doutorado. Estudos comparativos com pesquisadores de outros países, em áreas do conhecimento similares, são necessários para melhor compreensão dos presentes resultados.

Received on 12/02/19.

Accepted on $01 / 04 / 20$.

\section{INTRODUCTION}

Quantifying the performance of individual scholars or groups of scholars, departments, institutions, provinces/states/regions and countries has become an integral part of research policy, funding allocations, grant awarding, faculty hiring, promotion and tenure ${ }^{1}$. Academic publishing is a competitive business and editors strive to provide the best possible products to the scientific community ${ }^{2}$.

In Brazil there are two main science funding agencies, the Coordination for the Improvement of Higher Education Personnel (CAPES, Coordenação de Aperfeiçoamento de Pessoal de Nível Superior) and the National Council for the Development of Science and Technology (CNPq, Conselho Nacional de Desenvolvimento Científico e Tecnológico). $\mathrm{CNPq}$ is mainly dedicated to research funding, whereas CAPES evaluates and financially supports postgraduate courses. Moreover, CNPq provides a specific type of grant for researches, called scientific productivity fellowship, which classifies researchers into two main categories: 1 and 2, the former being further subdivided into four levels: $1 \mathrm{~A}, 1 \mathrm{~B}, 1 \mathrm{C}$ and $1 \mathrm{D}^{3}$.

According to CNPq Advisory Committee, the criteria for researchers' selection and classification in Medicine include, amongst several indicators, scientific production, human resources training, and contribution to innovation. Therefore, in order to be classified as a CNPq investigator in Medicine, the researcher must have met the following requirements in the previous decade: a) published at least 20 articles in scientific journals with an Impact Factor (IF) equal to or above 1; b) completed at least one $\mathrm{PhD}$ advisory; and c) to have a defined line of research and a present research project of scientific merit in the medical area.
A number of studies have assessed the profile and the scientific production of CNPq-supported researchers in several areas of knowledge ${ }^{1,4-6}$. The present study aims to describe the profile and scientific production of $\mathrm{CNPq}$ research grant recipients in the area of neuroscience.

\section{METHODS}

We selected $542 \mathrm{CNPq}$ fellows who were researchers in the medical area from a database, of which 94 (17.34\%) worked mainly with neuroscience according to a list provided by the research funding agency in May $2018^{7}$. Using the publicly available Lattes curriculum in the Lattes Platform (http://buscatextual.cnpq.br/buscatextual/busca.do? metodo=apresentar), we constructed a database containing information on each researcher in terms of institution, time since receiving the $\mathrm{PhD}$ degree, scientific production (published papers) and human resources training (supervision of undergraduate, master's degree and $\mathrm{PhD}$ students).

For the scientific production analysis, we considered all publications and advisories throughout the researcher's career, defined as the period comprised between the first publication and December 2017. We also analyzed publications and advisories in the past 5 years, considering the period between 2013 and 2017 (average duration of the scholarship).

\section{RESULTS}

Among the 94 researchers, there was a predominance of males $(\mathrm{n}=65 ; 69.14 \%)$. All researchers were distributed in eight Brazilian States: São Paulo ( $\mathrm{n}=49 ; 52.12 \%)$, Rio Grande do Sul ( $\mathrm{n}=22 ; 23.40 \%)$, Rio de Janeiro $(n=9 ; 9.57 \%)$, Minas Gerais $(n=5 ; 5.31 \%)$, Ceará $(n=4 ; 4.25 \%)$,

REVISTA BRASILEIRA DE EDUCAÇÃO MÉDICA

2 44 (2) : e049; 2020 
Santa Catarina $(n=3 ; 3.19 \%)$, Espirito Santo $(n=1 ; 1.06 \%)$ and Paraná $(\mathrm{n}=1,1.06 \%)$. Although neuroscience researchers were from 20 different institutions, $58.5 \%$ worked in only 3 of them, namely USP ( $n=30$ ), UFRGS $(\mathrm{n}=15)$ and UNIFESP $(\mathrm{n}=10)$. The median time since the $\mathrm{PhD}$ degree had been obtained was 18.27 years (range, 5-39).

The 94 researchers published 16,488 papers in scientific journals, with an average of 175.40 articles per researcher (ranging from 43 to 715 articles), of which 12,801 or $77.63 \%$ were indexed at Web of Science, with an average of 136.18 articles/researcher, while 10,166 or $61.65 \%$ were Scopus indexed, with an average of 108.14 articles/researcher (Table 1). Most articles published during the researchers' careers are A1 and A2, while per absolute number of researchers, the highest publication means are A2 (303.42 papers) and B1 (247.33 papers). The lowest average was at level 2 (116.69 per researcher). The same is also observed when evaluating the five-year period (2013-2017) (Table 1).

Over their careers, those researchers advised 1,279 undergraduate students, (median of 13.60; range: 0-68), 1,329 master's degree students (median of 14.13; range: $1-49$ ) and $970 \mathrm{PhD}$ students (median of 10.54; range: 0-42) (Table 2). We found a prevalence of undergraduate students, master's degree and $\mathrm{PhD}$ students at $\mathrm{A} 1$ and $\mathrm{A} 2$. However, when corrected by the scholarship, the highest average of undergraduate students advisory

\section{Table 1}

Distribution of researchers in the field of neuroscience, with a scientific productivity grant by the Brazilian Council for Scientific and Technological Development (CNPq), with respect to published papers.

\begin{tabular}{|ccccc|} 
Grant category (n=94) & \multicolumn{2}{c}{$\begin{array}{c}\text { Published papers } \\
\text { (career) }\end{array}$} & \multicolumn{2}{c|}{$\begin{array}{c}\text { Published papers } \\
(\mathbf{2 0 1 3 - 2 0 1 7 )}\end{array}$} \\
& $\mathbf{n}$ & $\%$ & $\mathbf{n}$ & $\%$ \\
\hline 1A (19) & 5,765 & 34.96 & 1,670 & 30.65 \\
\hline 1B (9) & 2,226 & 13.51 & 620 & 11.38 \\
\hline 1C (9) & 1,553 & 9.41 & 511 & 9.37 \\
\hline 1D (11) & 1,576 & 9.56 & 467 & 8.57 \\
\hline 2 (46) & 5,368 & 32.55 & 2,180 & 40.01 \\
\hline TOTAL & \multicolumn{2}{c}{$\mathbf{1 6 , 4 8 8}(\mathbf{1 0 0})$} & & $\mathbf{5 , 4 4 8}(\mathbf{1 0 0})$ \\
\hline
\end{tabular}

was in $\mathrm{B} 1$ researchers (20.11 students), while for master's degree and $\mathrm{PhD}$ students was in A1 researchers (21.57 and 21.15, respectively) (Table 2). The median $\mathrm{H}$-index at ISI of the fellows was 23.75 .

\section{DISCUSSION}

Researchers in the neuroscience area constitute the largest group in the medical area at CNPq (http://www.cnpq.br/web/guest/bolsistasvigentes). It is important to note the concentration of scientific output in a few Brazilian States, with just eight of them accounting for $100 \%$ of the researchers, and, most notably, a single State, São Paulo, accounting for over half (52.12\%) of all Brazilian neuroscience researchers.

The Brazilian postgraduate system (CAPES) has carried out an important expansion and decentralization in postgraduate programs in the last decade, decreasing the national system asymmetry (https://sucupira. capes.gov.br/sucupira/public/consultas/coleta/programa/quantitativos/ quantitativoRegiao.jsf;jsessionid=IpC19tcuSCVdbQWNHKsjYjWE. sucupira-213). However, even with efforts in this sense, $95.75 \%$ of neuroscience researchers are still concentrated in the South and Southeast regions, with a single State, Ceará, outside this area, reinforcing the Brazilian heterogeneous spatial distribution. This same spatial concentration of researchers in a few Brazilian States can also be observed in other research areas ${ }^{4,6,8}$, supporting the idea of specific government actions towards mitigating such regional differences ${ }^{9}$.

Our analysis showed that male researchers predominate, and although there are more female than male undergraduate and graduate students in many countries, there are relatively few female full professors, and gender inequalities in hiring, earnings, funding, satisfaction, and patenting persist. This fact was observed in our study, given that $69.14 \%$ of researchers in neuroscience in Brazil were males. In this sense, Lariviere et al. (2013) have presented a bibliometric analysis confirming that gender inequalities persist in research output worldwide ${ }^{10}$. Moreover, as expected, in Brazil the state of affairs is quite similar and women show a lower proportion in the higher positions in the academic career, that is, those positions associated with higher income and higher academic prestige ${ }^{11}$.

Another point emphasized by our study is the assessment of the scientific output by researchers in neuroscience in quantitative and qualitative terms through the analysis of bibliometric indicators. From the quantitative point of the view, our study showed an important scientific

Table 2

Distribution of researchers in the field of neuroscience, with a scientific productivity grant by the Brazilian Council for Scientific and Technological Development $(\mathrm{CNPq})$, with respect to training of human resources.

\begin{tabular}{|c|c|c|c|c|c|c|}
\hline \multirow[t]{2}{*}{ Grant category $(n=94)$} & \multicolumn{3}{|c|}{ Training of human resources (n) (\%) (career) } & \multicolumn{3}{|c|}{ Training of human resources (n) (\%) (2013-2017) } \\
\hline & SIS* & $\mathbf{M T}^{* *}$ & $\mathrm{PhD}^{* * *}$ & SIS* & $\mathbf{M T}^{* *}$ & $\mathrm{PhD}^{* * *}$ \\
\hline 1A (19) & $358(27.99)$ & $410(30.85)$ & $402(41.44)$ & $76(20.21)$ & $57(16.86)$ & $91(27.74)$ \\
\hline $1 \mathrm{~B}(9)$ & $181(14.16)$ & $138(10.38)$ & $109(11.23)$ & $15(3.98)$ & $22(6.50)$ & $34(10.36)$ \\
\hline $1 \mathrm{C}(9)$ & $57(4.45)$ & $139(10.45)$ & $89(9.17)$ & $23(6.12)$ & $18(5.32)$ & $29(8.84)$ \\
\hline 1D (11) & $138(10.78)$ & $161(12.11)$ & $107(11.03)$ & $29(7.71)$ & $43(12.72)$ & $56(17.07)$ \\
\hline $2(46)$ & $545(42.61)$ & $481(36.19)$ & $263(27.11)$ & $233(61.96)$ & $198(58.58)$ & $118(35.97)$ \\
\hline TOTAL (n) & 1,279 & 1,329 & 970 & 376 & 338 & 328 \\
\hline
\end{tabular}

${ }^{\star}$ Scientific initiation students; ${ }^{* *}$ Master; ${ }^{* *} \mathrm{PhD}$.

$3 \mid$\begin{tabular}{l|l} 
REVISTA BRASILEIRA DE EDUCAÇÃO MÉDICA \\
\hline 44 (2) : e049; 2020
\end{tabular} 
output with an expressive number of publications of scientific articles in periodicals indexed in the Web of Science and Scopus databases. These results are observed throughout the careers, as well as in the last five-year period. These data are similar to those observed for other medical specialties, according to our group's preliminary results ${ }^{5,12,13}$. This quantitative increment in scientific production possibly reflects the several fostering mechanisms implemented by the various national research support agencies ${ }^{14-18}$.

In a previous study, we evaluated the researchers in the field of neuroscience, during the triennium of 2006-2008. This cross-sectional study showed a group with high scientific productivity in terms of quality, with $61 \%$ of papers indexed in the Web of Science and $77.5 \%$ in the Scopus databases ${ }^{14}$. In the present study, $77.63 \%$ were indexed in the Web of Science, (an average of 136.18 articles/researcher), and $61.65 \%$ articles were indexed in the Scopus (an average of 108.14 articles/researcher) databases, therefore showing that neuroscience researchers have the highest percentage of indexed articles, when compared to other medical specialties ${ }^{19}$.

According to the CNPq Advisory Committee, the criteria for the selection and classification of scholarships include scientific output, training of human resources, contribution to innovation, coordination and participation in research projects, participation in editorial activities, and scientific management. One of the dimensions of the CNPq researcher is the training of human resources. In the present study, an important average of undergraduate students, master's degree and $\mathrm{PhD}$ students training is observed, both throughout the researchers' careers and in the assessed five-year period. These results are similar to other studies from different areas, involving scientific production and student training ${ }^{5,6,8}$.

Unfortunately, the current economic crisis has already resulted in federal and state science funding cuts, probably impairing Brazilian research and hampering scientific output increment in the next years ${ }^{20}$. In recent years, Brazilian scientists have faced a dramatic reduction in financial support for research and postgraduate programs ${ }^{20}$. However, one must highlight that recent budget restrictions and the discontinuity of successful programs can compromise the Brazilian scientific production and the postgraduate national system ${ }^{21}$.

Further studies addressing some important issues, such as research groups' productivity, collaborative efforts, and the impact of the scientific output might contribute to a better understanding of this dynamic area of research.

\section{ACKNOWLEDGMENTS}

To the Minas Gerais State Research Foundation-FAPEMIG, Minas Gerais, Brazil and the National Council for Scientific and Technological Development - CNPq, Brazil.

\section{REFERENCES}

1. Browman HI, Stergiou KI. Factors and indices are one thing, deciding who is scholarly, why they are scholarly, and the relative value of their scholarship is something else entirely. Ethics in Science and Environmental Politics. 2008;8(2):1-3.

2. Quevedo J, Nardi AE, da Silva A. Brazilian Journal of Psychiatry. Braz J Psychiatry. 2019;41(1):1-2.

3. Arruda D, Bezerra F, Neris VA, Toro PR, Wainer J. Brazilian computer science research: Gender and regional distributions. Scientometrics.
2009;79(3):651-665.

4. Santos NCF, Candido LFO, Kuppens CL. Produtividade em pesquisa do CNPq: análise do perfil dos pesquisadores da química. Quimica Nova. 2010;33(8):489-495.

5. Oliveira EA, Colosimo EA, Martelli DR, Quirino IG, Oliveira MC, Silva LS, et al. Comparison of Brazilian researchers in clinical medicine: are criteria for ranking well-adjusted? Scientometrics. 2012;90(2):429-443.

6. de Andrade RS, Martelli DRB, Almeida OP, Lopes MA, Swerts MSO, Pires FR, et al. Brazilian scientific production in Oral Medicine and Oral Pathology. Oral Surg Oral Med Oral Pathol Oral Radiol. 2018;125(2):17-181.

7. Anonymous. Produtividade em Pesquisa, Anexo III. 2017 ; ht tp://www.cnpq.br/view/journal_content/ 56 _ INSTANCE_0oED/10157/2958271?COMPANY_ID=10132.

8. Rodrigues LO, Gouvea MM, Marques FCC, Mourao SC. Overview of the scientific production in the Pharmacy area in Brazil: profile and oductivity of researchers granted with fellowships by the National Council for Scientific and Technological Development. Scientometrics. 2017;110(3):1157-1171.

9. Sturmer GCC, Viero MN, Silveira JL, Plentz RDL. Profile and scientific output analysis of physical therapy researchers with research productivityfellowship from the Brazilian National Council for Scientific and Technological Development. Braz J of Physical Therapy. 2013;17(3):41-48.

10. Lariviere V, Ni C, Gingras Y, Cronin B, Sugimoto CR. Bibliometrics: global gender disparities in science. Nature. 2013;504(7479):211-213.

11. Moschkovich M, Almeida AM. Gender Inequalities in Academic Career in Brazil. DADOS - Revista de Ciências Sociais. 2015;58(2):749-789.

12. Oliveira EA, Peicots-Filho R, Martelli DR, Oliveira MC, Quirino IG, Duarte MG, et al. Is there a correlation between journal impact factor and researchers' performance? A study comprising the fields of clinical nephrology and neurosciences. Scientometrics. 2013;97(4):149-160.

13. Martelli DRB, Oliveira MCL, Pinheiro SV, Santos ML, Dias VO, e Silva ACS, et al. Profile and scientific output of researchers recipients of CNPq productivity grant in the field of Medicine. Rev Ass Med Bras, 2019; in press.

14. Romano-Silva MA, Correa H, Oliveira MCL, Quirino IG, Colosimo EA, Martelli DR, et al. Perfil e análise da produção científica dos pesquisadores brasileiros em Neurociência Clínica. Ver Psiquiatr Clín. 2013;40(2):53-58.

15. Guimarães JA. A pesquisa médica e biomédica no Brasil. Comparações com o esempenho científico brasileiro e mundial. Cien Saude Colet. 2004;9(2):303-327.

16. Regalado A. Science in Brazil. Brazilian science: riding a gusher. Science. 2010;330(6009):1306-1312.

17. Oliveira EA, Pecoits-Filho R, Quirino IG, Oliveira MCL, Martelli DR, Lima LS, et al. Perfil e produção científica dos pesquisadores do CNPq nas áreas de Nefrologia e Urologia. J Bras de Nefrol. 2011;33(6):31-37.

18. Oliveira EA, Ribeiro ALP, Quirino IG, Oliveira MC, Martelli DR, Lima LS, et al. Perfil e produção científica dos pesquisadores do 
Conselho Nacional de Desenvolvimento Científico e Tecnológico na área de Cardiologia. Arq Bras Cardiol. 2011;97(4):186-193.

19. Mendes PHC, Martelli DRB, Souza WP, Quirino Filho S, Martelli Júnior $\mathrm{H}$. Perfil dos pesquisadores bolsistas de produtividade científica em medicina no CNPq, Brasil. Rev Bras Educ Med. 2010;34(4):535-541.

20. Gibney E. Brazilian science paralysed by economic slump. Nature. 2015;526(7571):16-17

21. Martelli Júnior $\mathrm{H}$, Martelli DRB, e Silva ACS, Oliveira MCL, Oliveira EA. Brazil's endangered postgraduate system. Science. 2019;363(6424):240

\section{AUTHORS' CONTRIBUTION}

GPD collected the data and wrote the manuscript, DRBM coded the data and performed the statistic tests, SMC and EAO assisted in the writing of the manuscript, RSA aided in the writing, formatting and adequacy of the manuscript, HMJ guided and reviewed the entire manuscript.

\section{CONFLICTS OF INTEREST}

None

\section{ADDRESS FOR CORRESPONDENCE}

Gabriela Pereira Dias. Primary Care Postgraduate Program, State University of Montes Claros (Unimontes), Montes Claros, Minas Gerais State, Brazil. CEP: 39400-000.

E-mail: gabi_pereiradias@hotmail.com 